Ola Bremnes

Sangskriver

Foto: Øyvind Arvola

\title{
Spør først
}

$\AA ̊$ bli syk kan noen ganger være oppkvikkende og bra for helsen. Det er ingenting som frisker opp så mye som en god sykdomsprat. Har du dramatisk anlegg og god fantasi, er det ingen grenser for hva du kan få ut av øresusen din.

En god sykdomshistorie er som en edel Bordeaux-vin: Den blir bare bedre med årene. Her er den hittil beste av mine. Den involverer i høyeste grad en lege. Dertil en seksåring (meg), en ung mor samt en revolver.

| 1961 slet jeg med øre-nese-halssykdom. En spesialist i småbyen Harstad skulle undersøke meg for å se om det var grunnlag for amputasjon. Ikke av hele hodet, men noe bak i svelget som de kalte «mandlene».

Jeg ante uråd og innhentet forsikringer om at undersøkelsen ville bli skånsom og at legen ikke under noen omstendigheter kom til å stikke blanke instrumenter inn i verken munn eller ører. Jeg hadde vært hos leger før, nemlig!

Vi reiste med hurtigruta til Harstad en solfylt sommerdag. Mamma leide meg inn på det gamle St. Elisabeth Hospital der vi satt og ventet noen dager eller uker $f \varnothing r$ døren åpnet seg. En tilsynelatende hyggelig doktor ønsket oss velkommen. Han besto for det meste av en hvit frakk og hadde en slags gruvelykt på hodet.

Jeg fikk en stol og gapte opp mens legen lyste meg inn i munnen og spurte meg om ferie og fotball og andre trivelige ting som små og store gutter liker.

Plutselig trakk han opp en blank strikkepinne med krok. Tingesten hadde kurs for høyre øregang med ambolt, sneglehus og trommehinne. Han skulle rett og slett stikke den inn i ørene mine, på tross av alle løfter og forsikringer.

Jeg reagerte momentant: Spratt ut av stolen, ned trappene og ut på gata. Det hjalp ikke hvor mye legen eller mamma ropte - de roper muligens fremdeles.
Til jul det året ønsket jeg meg en revolver. Jeg var midt inne i en cowboy-indianer-periode (som jeg som frilansmusiker ennå ikke er kommet ut av). Planen var å ta livet av den svikefulle legen i Harstad. Det sa jeg selvsagt ikke til foreldrene mine.

Revolver fikk jeg, med kulebelte og det hele. Jippi! Gleden sto i taket, men gikk fort over i enorm skuffelse: Det var bare en alminnelig lekepistol!

Det er skremmende å tenke på at jeg faktisk kunne ha blitt morder i en alder av 6 år. Legen i Harstad berget livet ved en ren tilfeldighet.

Moralen? Spør først. Grav siden. Enten pasienten er seks år eller seksti år.

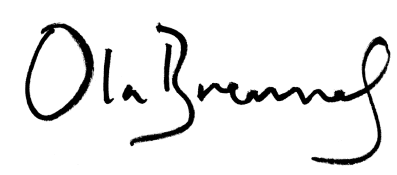

